\title{
Polystyrene nanoparticles induce stronger cellular and more durable humoral immune responses against an inactivated bovine herpesvirus 1 isolate
}

\section{Xingbo Liu}

Heilongjiang Bayi Agricultural University https://orcid.org/0000-0002-6714-9884

\section{Zhihao Xin}

heilongjiangbayi agriculture university

\section{Fan Zhang}

heilongjiangbayi agriculture university

Luyao zhang

heilongjiangbayi agriculture university

\section{Hanyu Yan}

Heilongjiang Bayi Agricultural University

Liwei Gu

Heilongjiang Bayi Agricultural University

Hongbo Ni ( $\nabla$ nihongbo@sina.com )

Heilongjiang Bayi Agricultural University

\section{Original article}

Keywords: Polystyrene nanoparticles, BoHV-1, Inactivated vaccine, Cell-mediated immunity

Posted Date: February 25th, 2020

DOI: https://doi.org/10.21203/rs.2.24337/v1

License: (9) This work is licensed under a Creative Commons Attribution 4.0 International License.

Read Full License 


\section{Abstract}

The inactivated bovine herpesvirus type 1 (BoHV-1) vaccines are generally safe and suitable for use in dairy and pregnant cattle, but induces weaker cellular immune responses and shorter antibody responses compared with the modified live virus vaccine. In this study, we used polystyrene (PS) nanoparticles (100 $\mathrm{nm}$ ) as a carrier for purified inactivated broken BoHV-1 to improve cellular and humoral immune responses compared with the traditional inactivated vaccine. Mice were injected intramuscularly with the inactivated complex mixed with ISA206 adjuvant. Transmission electron microscopy showed that the PS nanoparticles displayed broken BoHV-1 on their surfaces. After validation of BoHV-1 and gB gC gD gE tegument proteins, it proved that the BoHV-conjugated PS nanoparticles induced higher-titer and more durable antibody responses. The inactivated BoHV-PS nanoparticle complex elicited neutralizing antibodies (titer 2 6 ) in 5 weeks post-immunization in mice. The CD4/CD8 ratio was higher in mice immunized with PS nanoparticles compared with other groups. However, this ratio reached its maximum 1 week later than in mice immunized with ISA206+BoHV-1 or BoHV-1. Levels of interleukin (IL)-4, IL-6, and interferon- $y$ in followed similar patterns. In conclusion, this pilot study demonstrated that PS nanoparticles can adjuvant inactivated BoHV-1 vaccines, enhancing both cell-mediated immune responses and the duration of antibody responses. This study provides the foundation for a new development platform for inactivated vaccines, which can elicit potent cellular and humoral immune responses in animals and humans. The inactivated bovine herpesvirus type 1 (BoHV-1) vaccines are generally safe and suitable for use in dairy and pregnant cattle, but induces weaker cellular immune responses and shorter antibody responses compared with the modified live virus vaccine. In this study, we used polystyrene (PS) nanoparticles $(100 \mathrm{~nm})$ as a carrier for purified inactivated broken BoHV-1 to improve cellular and humoral immune responses compared with the traditional inactivated vaccine. Mice were injected intramuscularly with the inactivated complex mixed with ISA206 adjuvant. Transmission electron microscopy showed that the PS nanoparticles displayed broken BoHV-1 on their surfaces. After validation of BoHV-1 and $\mathrm{gB} \mathrm{gC} \mathrm{gD} \mathrm{gE} \mathrm{tegument} \mathrm{proteins,} \mathrm{it} \mathrm{proved} \mathrm{that} \mathrm{the} \mathrm{BoHV-conjugated} \mathrm{PS}$ nanoparticles induced higher-titer and more durable antibody responses. The inactivated BoHV-PS nanoparticle complex elicited neutralizing antibodies (titer 2 6 ) in 5 weeks post-immunization in mice. The CD4/CD8 ratio was higher in mice immunized with PS nanoparticles compared with other groups. However, this ratio reached its maximum 1 week later than in mice immunized with ISA206+BoHV-1 or BoHV-1. Levels of interleukin (IL)-4, IL-6, and interferon- $y$ in followed similar patterns. In conclusion, this pilot study demonstrated that PS nanoparticles can adjuvant inactivated BoHV-1 vaccines, enhancing both cell-mediated immune responses and the duration of antibody responses. This study provides the foundation for a new development platform for inactivated vaccines, which can elicit potent cellular and humoral immune responses in animals and humans.

\section{Introduction}

Bovine herpesvirus type 1 (BoHV-1) is a major cause of bovine respiratory diseases and other immunosuppressive diseases such as conjunctivitis, infectious bovine rhinotracheitis, balanoposthitis 
and abortion (Afroz et al. 2019). The BoHV-1 genome encodes more than 70 proteins (Jefferson et al. 2018) including 11 tegument proteins (gB, gC, gD, gE, gG, gH, gl, gL, gK, gM, and gN), all of which except for $\mathrm{gN}$ are glycoproteins (Pires de Mello et al. 2016). These glycoproteins are major targets of immune cells. The gB, gC, gD and gE envelope glycoproteins were reported to be most abundant in the viral tegument layer (Kaur and Chandra 2016). Therefore, these glycoproteins were chosen to develop subunit vaccines or diagnostic reagents (for instance, the gB protein was used by IDEXX).

Both modified live virus (MLV) vaccines and inactivated vaccines can prevent invasion of BoHV-1. However, the MLV vaccine [gE (US8)-deleted or gE-TK-deleted BoHV-1] induced stronger cellular immune responses than the inactivated vaccine. Among pregnant and dairy cattle, the MLV vaccine can induce more serious tissue lesions, including ovarian lesions that may lead to abortion, compared with the inactivated vaccine (Chase et al. 2017). For these reasons, we hypothesized that an adjuvant might improve cell-mediated immune responses against the inactivated BoHV- 1 vaccine. To this end, we found inspiration in nanomaterials, as it was previously reported that silica nanoparticles could improve the magnitude and duration of T cell responses (Cheng et al. 2017; Mahony et al. 2014; Mody et al. 2015; Mody et al. 2014; Mody et al. 2013).

As a non-degradable material, we hypothesized that polystyrene (PS) nanoparticles may have similar effects on immune responses. Generally, PS nanoparticles have been used as a model system to test the carrier effects of proteins and peptides due to their good biological compatibility and safety in cells and animals. Other advantages of PS nanoparticles include ease of preparation and modification of chemical groups, uniformity of diameter, and smooth surfaces. These advantages make PS nanoparticles ideal carriers for proteins and peptides in vitro and in vivo. Naked $175 \mathrm{~nm}$ PS nanoparticles induced secretion of cytokines [such as interleukin (IL)-4, IL-1 $\beta$, IL- 6 and tumor necrosis factor-a] in human peripheral blood mononuclear cells. They also induced immune responses mediated by $\mathrm{CD} 4^{+}$cells, $\mathrm{CD} 86^{+}$cells, and dendritic cells (DCs) (Frick et al. 2012). A 100-nm PS nanoparticle was also tested for uptake by human macrophages and monocytic cell lines (Oleg Lunov et al. 2011). The authors found that the nanoparticles could be taken up by macrophages, and that the optimal particle size for uptake was between $250 \mathrm{~nm}$ and $3 \mu \mathrm{m}$ (Oleg Lunov et al. 2011). Johrden et al. compared carboxyl-modified PS beads $(24,60,93,220$ and $340 \mathrm{~nm}$ in diameter) with adenovirus as carriers for ovalbumin (OVA). They found that following immunization with equivalent protein amounts, the antibody responses in PS nanoparticle-immunized animals were lower than those of adenovirus-immunized animals, but higher than those of animals immunized with soluble OVA. This pattern was the same irrespective of particle size. The authors demonstrated that the use of nanoparticles as carriers allowed the reduction of antigen dose to levels similar to immunization with soluble protein, and induced strongly enhanced antibody responses (Lena Johrden 1 and Oliver Wildner1 2013). Kumar et al. compared different shapes and sizes of PS nanoparticles as carriers for OVA in vivo and in vitro. They found that spherical nanoparticles (193 nm in diameter) induced Th1 biased responses. Spherical nanoparticles smaller than $193 \mathrm{~nm}$ induced both Th1 and Th2 responses (Kumar et al. 2015). Rod-shaped nanoparticles (376 nm and $1530 \mathrm{~nm}$ in length) also 
induced Th2 responses. Based on these data, we hypothesized that PS nanoparticles could be used as carriers for inactivated veterinary vaccines to improve the immune responses.

\section{Materials And Methods}

\section{Expression of $\mathrm{gB}, \mathrm{gC}, \mathrm{gD}$, and $\mathrm{gE}$ tegument proteins in MDBK cells}

To validate the humoral immune responses exactly, BoHV-1 and eukaryotic gB gC gD gE tegument protein had been prepared as follow. The full-length $g B, g C, g D$, and $g E$ genes (NC001847, GenBank) containing signal peptides and restriction sites were synthesized by TSingKe Biological Technology, Ltd. (Beijing, China). The gB, gC, gD and gE genes were cloned into the pcDNA4-Myc-hisB plasmid (Thermo Fisher, USA).

Madin-Darby Bovine Kidney (MDBK) cells (purchased from china institute of veterinary drug control, IVDC Beijing,China) were transfected with the eukaryotic expression vectors (pcDNA4.0- $g B$-his, pcDNA4.0- $g C$ his, pcDNA4.0-gD-his, pcDNA4.0-gE-his) using a DNA Transfect Kit (Enriching Biotechnology, Shanghai, China). MDBK cells were cultured $48 \mathrm{~h}$ before the medium was exchanged for selective medium [Dulbecco's modified Eagle's medium (DMEM) containing $400 \mu \mathrm{g} / \mathrm{mL}$ Zeocin and 10\% fetal bovine serum (FBS) (BI, Israel)]. After $48 \mathrm{~h}$, the proteins were validated by indirect immunofluorescence assay (IFA) with rabbit anti-BoHV-1 polyclonal antibody. The tegument proteins were secreted to the culture guided by the signal peptides in the sequences and were purified using a Mag25K/NTA Ni protein purification kit (Enriching Biotechnology, Shanghai, China). Protein purity was assessed using SDS-PAGE and Western blotting (his tag).

\section{Preparation of virus}

BoHV-1 was purchased from the China Institute of Veterinary Drug Control. MDBK cells were inoculated with BoHV-1 in DMEM containing 10\% FBS. After $48 \mathrm{~h}$, the cells were centrifuged at $12,000 \times \mathrm{g}$ for $10 \mathrm{~min}$ and supernatants were collected. The supernatants $(600 \mathrm{~mL})$ were centrifuged at $100,000 \times g$ for 30 min to pelleted BoHV-1. The precipitate (containing broken BoHV-1) was resuspended in phosphate-buffered saline (PBS) and the medium was discarded. Viral concentrations were determined using a bicinchoninic acid (BCA) protein assay kit (Thermo Fisher, USA) and normalized to $2 \mathrm{mg} / \mathrm{mL}$.

\section{Preparation of PS nanoparticles conjugated to BoHV-1}

The 100-nm PS nanoparticles were purchased from Enriching Biotechnology Co., Ltd. (Shanghai, China). The PS nanoparticles were diluted 10-fold in PBS, pH 6.0, and activated with 1-(3dimethylaminopropyl)-3-ethylcarbodiimide hydrochloride $(1 \mathrm{mg} / \mathrm{mL})$ and $\mathrm{N}$-hydroxysuccinimide (5 $\mathrm{mg} / \mathrm{mL}$ ) at $37^{\circ} \mathrm{C}$ for $15 \mathrm{~min}$. The activated PS nanoparticles were centrifuged for $20 \mathrm{~min}$ at $13,000 \times \mathrm{g}$ and the supernatant was discarded. The nanoparticles were resuspended in $0.5 \mathrm{~mL}$ of PBS, pH 6.0, and subjected to ultrasonic vibration for $5 \mathrm{~min}$ in an ultrasonic cleaner. BoHV-1 $(10,20,30,40,50,60,70,80$, 90 , or $100 \mu \mathrm{g}$ ) was conjugated to $1 \mathrm{~mL}$ of activated nanoparticles at $37^{\circ} \mathrm{C}$ for $1 \mathrm{~h}$ to determine the optimal 
conjugation ratio. BoHV-1 remaining in supernatants was measured by BCA assay after centrifugation. The optimal conjugation ratio was $50 \mu \mathrm{g} \mathrm{BoHV}-1$ per $1 \mathrm{~mL}$ of diluted nanoparticles. The conjugated complex (PS nanoparticles+BoHV-1) was resuspended in $500 \mu \mathrm{L}$ of PBS, $\mathrm{pH} 7.0$, and subjected to ultrasonic vibration for $5 \mathrm{~min}$ in an ultrasonic cleaner. Finally, the complex was inactivated with $0.2 \%$ formaldehyde at room temperature for $72 \mathrm{~h}$ (Hernando Duque* and Letchworth* 1989).

\section{Observation of PS nanoparticles conjugated to BoHV-1 by transmission electron microscopy (TEM)}

The conjugated complex and purified BoHV-1 were diluted 10-fold in PBS, pH 7.4, and dried onto carboncoated copper grids prior to observation. The size and morphology of PS nanoparticles were determined by field emission gun-transmission electron microscopy (FEG-TEM, JEOL JEM 2100F, Japan) at an operational voltage of $200 \mathrm{kV}$. The diffraction ring patterns, lattice fringes, and d-spacing were examined in high resolution mode.

\section{Preparation of inactivated vaccine}

MONTANIDE ${ }^{\text {TM }}$ ISA 206 VG $\left(5 \mathrm{~mL}\right.$ warmed to $\left.31 \pm 1^{\circ} \mathrm{C}\right)$ was agitated at $350 \mathrm{~g} / \mathrm{min}$ for $5 \mathrm{~min}$ and added to $5 \mathrm{~mL}$ of inactivated BoHV-1/PS nanoparticle complex. The mixture was agitated for $5 \mathrm{~min}$ at $350 \times \mathrm{g}$ and placed at $20^{\circ} \mathrm{C}$ for $1 \mathrm{~h}$ with minimal transport and agitation.

\section{Animals and vaccination procedure}

Female specific pathogen-free Kunming mice (8 weeks old) were purchased from SPF Biotechnology Co., Ltd. (Beijing, China) and housed in individually vented rodent caging systems at the Heilongjiang Bayi Agricultural University (Daqing, China). Animal procedures were approved by the University of Heilongjiang Bayi Agriculture University Institutional Animal Care and Use Committee in accordance with the mandates of the Association for Assessment and Accreditation of Laboratory Animal Care (AAALAC), AAALAC International, and the Public Health Service Office of Laboratory Animal Welfare. Three hundred mice were randomly allocated to one of six groups (PBS, PS nano, in-BoHV-1, PS+BoHV-1, ISA206+BoHV1, ISA206+PS +BoHV-1). Mice were injected twice with $50 \mu \mathrm{g}$ of BoHV-1 into the quadriceps femoris muscle at 4-week interval. The control groups were injected with equal volumes of diluted PS nano or PBS alone. Five mice were narcosis using ketamine $(10 \mathrm{mg} / \mathrm{kg})$ during vaccination and blood collection by enucleating the eyeball, and the blood was collected in heparin sodium anticoagulant tubes for flow cytometry assays. Blood $(200 \mu \mathrm{L})$ was sampled from another five mice via the tail vein and collected in $1.5 \mathrm{~mL}$ Eppendorf tubes. After clotting, serum was used for enzyme-linked immunosorbent assays (ELISAs).

\section{Flow cytometry analysis of CD4+ and CD8+ T cells}

Peripheral blood containing anticoagulant was lysed with $2 \mathrm{~mL}$ of red blood lysis buffer, gently mixed immediately by pipetting, and allowed to stand for $5 \mathrm{~min}$ at room temperature. Next, the blood was centrifuged (400×g for $5 \mathrm{~min}$ ). Lymphocytes were collected and washed twice with PBS, pH 7.4, then 
resuspended in $100 \mu \mathrm{L}$ of sterile PBS. The lymphocytes were stained with $1 \mu \mathrm{L}$ of anti-CD4 monoclonal antibody [fluorescein isothiocyanate (FITC)-conjugated] and $1 \mu \mathrm{L}$ of anti-CD8 monoclonal antibody [phycoerythrin (PE)-conjugated; BD Bioscience] in the dark. The stained lymphocytes were washed twice and resuspended in $200 \mu \mathrm{L}$ of PBS (Slebioda et al. 2017). Finally, the frequencies of CD4 ${ }^{+} \mathrm{T}$ cells and $\mathrm{CD}^{+} \mathrm{T}$ cells were assessed using a flow cytometer (Beckman Coulter, USA).

\section{ELISA to detect total IgG binding to $\mathrm{gB}, \mathrm{gC}, \mathrm{gD}, \mathrm{gE}$ protein and BoHV-1}

The ultracentrifuged BoHV-1 and gB, gC, gD, and gE proteins (2.1) expressed in MDBK cells (validated by indirect IFA using rabbit anti-BoHV-1 polyclonal antibody purified by protein A chromatography) were coated in 96-well ELISA plates (Corning, USA) at concentrations of $1 \mu \mathrm{g} / \mathrm{mL}$ (Batra et al. 2017). The plates were blocked overnight at $4{ }^{\circ} \mathrm{C}$ with $1 \%$ bovine serum albumin (Amerisco, USA). The collected serum was diluted 300 -fold in PBS, pH 7.4, containing $0.1 \%$ Tween- 20 for BoHV- 1 and 100 -fold for gB, gC, $\mathrm{gD}$, and $\mathrm{gE}$ proteins. The plates were incubated for $1 \mathrm{~h}$ at $37^{\circ} \mathrm{C}$ and washed three times. Horseradish peroxidase (HRP)-labeled secondary antibody $(100 \mu \mathrm{L})$ was added and incubated for $45 \mathrm{~min}$ at $37^{\circ} \mathrm{C}$. The wash step was repeated. Trimethylbenzidine (TMB) $(100 \mu \mathrm{L})$ (Solarbio Life Science, Beijing) was added to each well and incubated for $15 \mathrm{~min}$ at room temperature. Finally, the reaction was stopped with $50 \mu \mathrm{L}$ of $2 \mathrm{M} \mathrm{H}_{2} \mathrm{SO}_{4}$, and absorbance at $450 \mathrm{~nm}$ was measured using a microplate reader (BioTEK ELx800 USA).

\section{Detection of virus-neutralizing antibody}

Inactivated serum $(25 \mu \mathrm{L})$ obtained 5 weeks post-immunization was diluted $(1: 8,1: 16,1: 32,1: 64$ and $1: 128)$ and mixed with 100 tissue culture infectious doses $\left(\mathrm{TCID}_{50}\right)$ of BoHV-1 $(25 \mu \mathrm{L})$ in DMEM. The mixture was incubated for $1 \mathrm{~h}$ at $37^{\circ} \mathrm{C}$ to neutralize the virus, then added to monolayer MDBK cells. Cells were observed for the appearance of cytopathic effect for 7 days (Chung et al. 2016). Titers of neutralizing antibodies were calculated using the Karber method(Edens et al. 2015).

\section{ELISAs to de termine serum IL-4, IL-6, and interferon (IFN)-y levels}

IL- 4, IL-6, and IFN-y cytokine ELISA kits were purchased from Proteintech Co., Ltd. (USA). The protocol below was followed to determine levels of IL-4, IL-6, and IFN- $\gamma$ in the serum collected in 2.7. The sera and 10 -fold diluted standards $(25 \mu \mathrm{L})$ were pipetted into wells containing $75 \mu \mathrm{L}$ of sample dilution buffer and incubated for $120 \mathrm{~min}$ at $37^{\circ} \mathrm{C}$. The plates were washed and spun dry four times. Diluent antibody solution $(100 \mu \mathrm{L})$ was transferred to the wells and incubated for $2 \mathrm{~h}$ at $37^{\circ} \mathrm{C}$. After washing, diluent HRP solution $(100 \mu \mathrm{L})$ was added to wells and incubated for $20 \mathrm{~min}$. After a final wash, TMB substrate was added to wells and incubated for $15 \mathrm{~min}$. The reaction was stopped using stop solution (50 $\mu \mathrm{L})$. Absorbance was measured at $450 \mathrm{~nm}$ and $630 \mathrm{~nm}$ immediately (BioTEK ELx800 USA).

\section{Statistical analyses}

Results were analyzed by one-way analysis of variance and differences between groups were assessed using Tukey's honestly significant difference test in GraphPad Prism 7.0. 


\section{Results}

\section{The $\mathrm{gB}, \mathrm{gC}, \mathrm{gD}$, and $\mathrm{gE}$ tegument proteins were expressed in MDBK cells}

Double digestion of recombinant plasmids showed that the eukaryotic expression vectors were constructed correctly.

SDS-PAGE showed that the $\mathrm{gB}, \mathrm{gC}, \mathrm{gD}$, and $\mathrm{gE}$ proteins had similar molecular weights (about $180 \mathrm{kDa}$ and $60 \mathrm{kDa}$ ) but that two protein bands were present, which were unexpected (Figure 1A). The IFA confirmed that the $\mathrm{gB}, \mathrm{gC}, \mathrm{gD}$, and $\mathrm{gE}$ proteins were expressed successfully and maintained natural structure in MDBK cells validated by rabbit anti-BoHV-1 polyclonal antibody (Figure 1B).

\section{PS nanoparticles conjugated with BoHV-1 were observed by TEM}

By TEM, the naked $100 \mathrm{~nm}$ PS nanoparticles were monodisperse (Figure 2A) and approximately 95-110 $\mathrm{nm}$ in diameter prior to conjugation with BoHV-1. The ultra-centrifuged BoHV-1 was about $50 \mathrm{~nm}$ (Figure 2C), comparing with other standard BoHV-1 (about $100 \mathrm{~nm}$ ) (Figure 2D). The diameter increased to approximately $150 \mathrm{~nm}$ after conjugation with BoHV-1 (Figure 2B). Because the BoHV-1 was broken by $100,000 \times g$ centrifugation. This result indicated that BoHV-1 was successfully conjugated to PS nanoparticles (Figure 2B).

\section{Total IgG responses against $\mathrm{gB}, \mathrm{gC}, \mathrm{gD}$, and $\mathrm{gE}$ proteins and BoHV-1 determined by ELISA}

Antibody titers against BoHV-1 reached their maximum 3 weeks post-immunization, then decreased slowly, persisting for more than 10 weeks. Although antibody titers in the PS+ISA206 group rose later than in the ISA206 group, they also decreased more slowly than in the ISA206 group, thus resulting in a longer duration of the humoral immune response (Figure $3 \mathrm{~A}$ ). Antibody titers against the gC protein (Figure $3 C$ ) reached their maxima 3 weeks post-immunization, 1 week earlier than antibody titers against the $\mathrm{gB}, \mathrm{gD}$ and gE proteins (Figure 3B, D and E). Judging from the absorbance at $450 \mathrm{~nm}$, antibody titers against the gD protein were higher than those against other proteins from weeks 3 to 5 postimmunization (Figure 3D), and persisted as long as those against other proteins. Comparing the antibody titers against the gB protein in different groups showed that the titers of the PS+ISA206+BoHV-1 and ISA206+BoHV-1 groups were significantly different, with the former reaching its maximum 5 weeks postimmunization, 1 or 2 weeks later than for the gC, gD, and gE proteins.

BoHV-1-neutralizing antibody titers in the PS+ISA206+BoHV-1 group $\left(\sim 2^{6}\right)$ were higher than in the other groups 5 weeks post-immunization. The neutralizing titers in the PS+BoHV-1 group were similar to those of the ISA206+BoHV-1 group (Figure 3F). 
Based on the absorbance at $450 \mathrm{~nm}$, secretion of IL-4 was induced by ISA206 and BoHV-1, but naked PS nanoparticles could not induce significant production of IL-4 (Figure 4A).

The IL- 6 levels in the PS+ISA206+BoHV-1 group reached their maximum at 5 weeks post-immunization, two weeks delayed compared with the ISA206+BoHV-1 group but with higher maximum levels (Figure 4B). Naked PS nanoparticles also did not induce secretion of IL-6. Levels of serum IFN- $\gamma$ reached their maxima 3 weeks post-immunization in the ISA206+BoHV-1 group, weeks earlier than in the PS+ISA206+BoHV-1 group but with a lower maximum (Figure 4C). Naked PS nanoparticles induced lowlevel secretion of IFN- $y$, by contrast with IL-4 and IL-6. Serum cytokine levels in the PS and PS+ISA206+BoHV-1 groups were higher and persisted longer than levels in the PS+BoHV-1 and PS groups.

The CD4/CD8 ratio was highest in the PS+ISA206 group, followed by the PS+BoHV-1 and PS nanoparticles group, and then by the ISA206+BoHV-1 and In-BoHV-1 groups. The CD4/CD8 ratio in the PS+ISA206+BoHV-1 group reached a higher maximum value 1 week earlier compared with the PS+BoHV1 group (Figure 4D). The CD4/CD8 ratios of groups that received PS nanoparticles were higher than those of groups that did not receive nanoparticles. This finding indicated that the ISA206 adjuvant alone was unable to induce strong $T$ cell responses.

\section{Discussion}

As we hypothesized, PS nanoparticles acted as an adjuvant to conjugated BoHV-1, inducing stronger T cell responses and more durable antibody responses than ISA206 adjuvant. This work forms the basis of a developmental platform for potentiating cell-mediated and humoral immune responses against inactivated vaccines.

The CD4/CD8 ratio reached its maximum 5 weeks post-immunization, then decreased slowly until 10 weeks. The CD4/CD8 ratio of the PS + ISA206 + BoHV-1 group was higher than that of other groups. The increase in $\mathrm{CD} 4^{+} \mathrm{T}$ cell frequency suggests that the PS nanoparticles induced Th 1 cell differentiation (Frick et al. 2012). It was reported that optimal vaccine-induced protective immunity depends on contributions from both CD4 ${ }^{+} T$ cells and antibodies (Farris et al. 2010). Frick et al. showed that functionalized PS nanoparticles triggered human DC maturation resulting in enhanced $\mathrm{CD} 4^{+} \mathrm{T}$ cell activation (Frick et al. 2012). The PS nanoparticles also have been taken up by immune cells resulting in BoHV-1 delivery to both MHC class I and MHC class II antigen presentation pathways, resulting in further $\mathrm{CD}^{+}{ }^{+} \mathrm{T}$ cell activation (Stano et al. 2012). Elevated serum levels of IL- 4 and IL-6 also suggested that Th2 cells had differentiated in response to immunization. To better understand the mechanisms underlying cellular immune responses to PS nanoparticles conjugated to BoHV-1, more data will be needed at the level of T cells and other immune cells. However, our results suggest that the PS nanoparticles were safer than ISA206. Because IL-4 is associated with toxicity, increased secretion of IL-4 may signify an ongoing inflammatory reaction (Gui et al. 2011; Park et al. 2010). Comparing the PS + ISA206 + BoHV-1 group with others, alterations in IFN- $\gamma$ levels indicated that cellular immune responses had been enhanced. Judging 
from the results above, the improved cell responses were primarily due to PS nanoparticles, because levels of IFN- $y$ in the PS + ISA206 + BoHV-1 and PS nano groups were higher than those in the ISA206 + BoHV-1 group. Secretion of IFN-y indicated that Th1 cells were activated and that cellular immune responses had been initiated (Anne et al. 2018). Secretion of IL-4 and IL-6 signified that Th2 cells were activated and that antibody was being produced (LA. Babiuk*1996).

To validate the humoral immune responses, BoHV-1 was purified by ultracentrifugation and the $\mathrm{gB}, \mathrm{gC}$, $\mathrm{gD}$, and $\mathrm{gE}$ proteins were expressed in MDBK cells. The TEM results show that BoHV-1 was broken up after ultracentrifuged by $100,000 \times \mathrm{g}$ for $30 \mathrm{~min}$ (Fig. 2C \&D)(Barber et al. 2017). The gB, gC, and gD proteins had been validated as subunit vaccine candidates and conferred significant protection from BoHV-1 challenge when formulated with an effective adjuvant(* 1997; Blanc et al. 2012; J. CHARLES WHITBECK 1988; Keil et al. 2005; Keil et al. 2010; Levings et al. 2015; M.J. Kaashoek"' and Oirschot ${ }^{\star} \$$ 1998). The gE protein could also elicit neutralizing antibodies, although it was a virulence factor of BoHV1 (van Drunen Littel-van den Hurk 2006). Interestingly, we found that the gB, gC, gD and gE proteins had similar molecular weights (about $130 \sim 180 \mathrm{kDa}$ and $60 \mathrm{kDa}$ ) by SDS-PAGE and Western Blotting (his tag) (Fig. 2A). This result was unexpected (Fig. 1A) based on the theoretical molecular weights of these proteins (gC 55.4 kDa, gD 44.9 kDa, gE 26.9 kDa; Uniprot.org). Chowdhury et al. reported the molecular weight of gC as $90 \mathrm{kDa}$, when it assembled into homodimers (* 1997). Keil et al. showed that the molecular weight of gB was $130 \mathrm{kDa}$, until it was cleaved into a 72-kDa N-terminal subunit and a 55-kDa C-terminal subunit (Keil et al. 2005). The molecular weight of the gE protein (55 kDa, $103 \mathrm{kDa}$, and $137 \mathrm{kDa}$ ) differed based on its levels of phosphorylation (Shaw et al. 2000). The molecular weight of native gD protein was $72 \mathrm{kDa}$. However, the apparent molecular weight of the gD protein expressed by MDBK cells was about $130 \mathrm{kDa}$, significantly different from its theoretical molecular weight (XIAOPING LIANG 1995) (S. VAN DRUNEN LITI-EL-VAN DEN HURK 1995). After comparing the SDS-PAGE and Western Blotting, it was found that the bands at $130 \mathrm{kDa}-180 \mathrm{kDa}$ was the proteins, and the bands at $60 \mathrm{kDa}$ were not the tegument proteins. The IFA (Fig. 1B) results showed that the recombinant proteins were bound by an anti-BoHV-1 polyclonal antibody, indicating that the proteins were expressed and maintained their native structure.

The humoral immune response against BoHV-1 was improved by its conjugation to PS nanoparticles. PS nanoparticles conjugated with BoHV-1 not only improved secretion of antibody, but also lengthened the duration of antibody responses. One explanation may be that BoHV-1 was conjugated with PS nanoparticles via chemical bonds, and BoHV-1 was released gradually and degraded. Antibody titers against the $\mathrm{gC}$ protein reached their maximum by week 3 post-immunization, one week earlier than other proteins. One explanation for this result may be that $\mathrm{gC}$ binds heparan sulfate proteoglycan, making it easily recognized by antigen-presenting cells (Jones and Chowdhury 2007). The generation of anti-gC antibodies needs to be explored further in cattle, as it may mirror that in mice. If so, the gC protein could represent a target for early diagnosis of BoHV-1 infection. Antibody titers against gB protein reached their maximum 5 weeks post-immunization, one week later than the $\mathrm{gD}$ and $\mathrm{gE}$ proteins. The antibody titers against the gD protein confirmed the conclusion that the gD protein expressed by eukaryotic cells could be used as a diagnostic target (Brewer et al. 2017). Usually, the gB protein has been used to assess BoHV- 
1 molecular evolution (Hidayati et al. 2018). It was reported that the gE gene was a duplicated nonessential gene, but it also could bound to receptors on cell membranes, and induced viral invasion of the trigeminus(M.J. Kaashoek"' and Oirschot*\$ 1998). The generation of antibody titers against the gE protein meant that the $\mathrm{gE}$ protein could be recognized by immune cells, and induced immune responses. Antibodies against BoHV-1, gB, gC, and gD persisted for more than 10 weeks. The OD450 values for serum antibody were above 0.4 for the PS nano + ISA206 + BoHV-1 group, signifying that immune cells were activated for prolonged durations.

The BoHV-1 neutralizing antibody titers 5 weeks post-immunization indicated that PS nanoparticles displayed BoHV-1 on its surface successfully, and elicited neutralizing antibodies to the same extent as a traditional inactivated vaccine (titer $\sim 2^{6}$ ) (Chung et al. 2016). Protection of cattle against BoHV-1 challenge $\left(3 \mathrm{~mL}, 10^{7.0} \mathrm{TCID}_{50}\right)$ required neutralizing antibody titers above $2^{3}$ (Chung et al. 2016) .

The enhanced cell and humoral immune responses in the PS + ISA206 + BoHV-1 group were a combined function of BoHV-1, ISA206 adjuvant and PS nanoparticles. The mechanisms may be as follows. The nanoparticles can deliver antigen to DCs for cross-presentation to antigen-specific T cells (Rietscher et al. 2016). Nanoparticles can be efficiently engulfed by DCs and induce DC maturation and cytokine release, activating antigen-specific immune responses and enhancing T cell proliferation, IFN-y production and generation of cytotoxic T lymphocytes (Dudek et al. 2018). The traditional adjuvant ISA206 is a water-oilwater emulsion, which may maintain the native structures of antigen better than water-oil adjuvants (Fuentealba et al. 2019; G.F. El-Bagoury1 and Darwish2 2010; Zhugunissov et al. 2018).

In this study, we showed that PS nanoparticles could improve the strength of cell-mediated immune responses and the duration of humoral immune responses against an inactivated BoHV-1 vaccine. Nonbiodegradable nanomaterials (PS, silica, gold, silver, etc.) have been applied in diagnostic fields and for drug delivery (Li et al. 2019; Mody et al. 2014; Mody et al. 2013) because of their biocompatibility and their diverse shapes and diameters. Injection of non-biodegradable nanomaterials may be unsafe when animal products (such as meat or milk) are consumed by humans. Therefore, selecting biodegradable nanoparticles to replace the PS nanoparticles will be our ultimate aim. Biodegradable nanomaterials [e.g., dextran, poly (lactic-co-glycolic acid), chitosan, polyethylene glycol, pullulan, and peptides] have been applied in drug delivery and cancer therapy because of their safety and degradation characteristics in vivo (Brewer et al. 2017; Gheibi Hayat and Darroudi 2019; Ho et al. 2018; Hong et al. 2017; Jiang et al. 2013; Liang et al. 2019; Mona Gupta 2004; Xiaobo Fan1 et al. 2016). Thus, these materials may be candidates for future research.

In conclusion, we showed that PS nanoparticles improved cellular immune responses and lengthened the duration of antibody responses against inactivated BoHV-1. Based on these results, it may now be possible to develop a complex inactivated BoHV-1 vaccine that induces strong cellular and humoral immune responses, which would be safe for use in dairy and pregnant cattle. And biodegradable nanoparticles will replace the PS nanoparticles is necessary in the future research for safe animal products. 


\section{Declarations}

Authors' contributions: Mr Xingbo Liu and Mr hongbo Ni conceived and designed research. Mr Xingbo Liu and Mr Zhihao Xin conducted experiments. Ms Fan zhang , Ms Luyao zhang, and Liwei Gu contributed new reagents or analytical tools. Ms hanyu Yan analyzed data. Mr Xingbo Liu wrote the manuscript. All authors read and approved the manuscript.

\section{Funding}

This study was supported by the Government on local Science and Technology development (No. ZY18C07-16)

\section{Compliance with ethical standards}

The study was approved by the Animal Experiments Committee of the Heilongjiang Bayi Agricultural University.

\section{Conflict of interest statement}

No potential conflict of interest.

\section{Ethics approval and consent to participate}

All applicable international, national, and/or institutional guidelines for the care and use of animals were followed.

\section{Consent for publication}

Yes.

\section{Availability of data and material}

All data and materials are true and reliable

\section{References}

SIC (1997) Fine mapping of bovine herpesvirus 1 (BHV-1) glycoprotein C neutralizing epitopes by typespecific monoclonal antibodies and synthetic peptides. 58:309-314.

Afroz S, Brownlie R, Fodje M, van Drunen Littel-van den Hurk S (2019) The bovine herpesvirus-1 major tegument protein, VP8, interacts with host HSP60 concomitant with deregulation of mitochondrial function. Virus Res 261:37-49. https://doi.org/10.1016/j.virusres.2018.12.006

Anne TRV, Rinehart CL, Buterbaugh RE, Bauer MJ, Young AJ, Blaha ML, Klein AL, Chase CCL (2018) Cellmediated and humoral immune responses to bovine herpesvirus type 1 and bovine viral diarrhea virus in 
calves following administration of a killed-virus vaccine and bovine herpesvirus type 1 challenge. AJVR 79(11):13.

Barber KA, Daugherty HC, Ander SE, Jefferson VA, Shack LA, Pechan T, Nanduri B, Meyer F (2017) Protein Composition of the Bovine Herpesvirus 1.1 Virion. Vet Sci 4(1). https://doi.org/10.3390/vetsci4010011

Batra SA, Shanthalingam S, Donofrio G, Haldorson GJ, Chowdhury S, White SN, Srikumaran S (2017) Immunization of bighorn sheep against Mannheimia haemolytica with a bovine herpesvirus 1-vectored vaccine. Vaccine 35(12):1630-1636. https://doi.org/10.1016/j.vaccine.2017.02.006

Blanc AM, Berois MB, Tome LM, Epstein AL, Arbiza JR (2012) Induction of humoral responses to BHV-1 glycoprotein D expressed by HSV-1 amplicon vectors. J Vet Sci 13(1):59-65.

https://doi.org/10.4142/jvs.2012.13.1.59

Brewer MG, DiPiazza A, Acklin J, Feng C, Sant AJ, Dewhurst S (2017) Nanoparticles decorated with viral antigens are more immunogenic at low surface density. Vaccine 35(5):774-781.

https://doi.org/10.1016/j.vaccine.2016.12.049

Chase CCL, Fulton RW, O'Toole D, Gillette B, Daly RF, Perry G, Clement T (2017) Bovine herpesvirus 1 modified live virus vaccines for cattle reproduction: Balancing protection with undesired effects. Vet Microbiol 206:69-77. https://doi.org/10.1016/j.vetmic.2017.03.016

Cheng J, Wen S, Wang S, Hao P, Cheng Z, Liu Y, Zhao P, Liu J (2017) gp85 protein vaccine adjuvanted with silica nanoparticles against ALV-J in chickens. Vaccine 35(2):293-298.

https://doi.org/10.1016/j.vaccine.2016.11.077

Chung YC, Shen HY, Cheng LT, Liu SS, Chu CY (2016) Effectiveness of a BHV-1/BEFV bivalent vaccine against bovine herpesvirus type 1 infection in cattle. Res Vet Sci 109:161-165.

https://doi.org/10.1016/j.rvsc.2016.10.004

Dudek K, Bednarek D, Ayling RD, Szczotka M, Iwan E, Kocki J (2018) Analysis of the immune response of calves to various saponin-based adjuvants for an experimental Mycoplasma bovis vaccine. Acta Vet Hung 66(2):226-240. https://doi.org/10.1556/004.2018.021

Edens C, Dybdahl-Sissoko NC, Weldon WC, Oberste MS, Prausnitz MR (2015) Inactivated polio vaccination using a microneedle patch is immunogenic in the rhesus macaque. Vaccine 33(37):46834690. https://doi.org/10.1016/j.vaccine.2015.01.089

Farris CM, Morrison SG, Morrison RP (2010) CD4+ T Cells and Antibody Are Required for Optimal Major Outer Membrane Protein Vaccine-Induced Immunity to Chlamydia muridarum Genital Infection. Infection and Immunity 78(10):4374-4383. https://doi.org/10.1128/iai.00622-10

Frick SU, Bacher N, Baier G, Mailander V, Landfester K, Steinbrink K (2012) Functionalized polystyrene nanoparticles trigger human dendritic cell maturation resulting in enhanced CD4+ T cell activation. 
Macromol Biosci 12(12):1637-1647. https://doi.org/10.1002/mabi.201200223

Fuentealba NA, Sguazza GH, Zanuzzi CN, Bravi ME, Scrochi MR, Valera AR, Corva SG, Gimeno EJ, Pecoraro MR, Galosi CM (2019) Immunoprotective response induced by recombinant glycoprotein D in the BALB/c respiratory mouse model of Equid alphaherpesvirus 1 infection. Rev Argent Microbiol 51(2):119-129. https://doi.org/10.1016/j.ram.2018.05.004

G.F. El-Bagoury ASE-H, Darwish EAE-EaDM (2010) Comparative Evaluation of Inactivated IBR Vaccines Formulated with Montanide ISA 25, 50 and 206. Benha Vet Med J 21(2):10.

Gheibi Hayat SM, Darroudi M (2019) Nanovaccine: A novel approach in immunization. J Cell Physiol. https://doi.org/10.1002/jcp.28120

Gui S, Zhang Z, Zheng L, Cui Y, Liu X, Li N, Sang X, Sun Q, Gao G, Cheng Z, Cheng J, Wang L, Tang M, Hong $F(2011)$ Molecular mechanism of kidney injury of mice caused by exposure to titanium dioxide nanoparticles. J Hazard Mater 195:365-370. https://doi.org/10.1016/j.jhazmat.2011.08.055

Hernando Duque RLM, Barbara A. Israel and, Letchworth GJ (1989) Effects of formalin inactivation on bovine herpes virus- 1 glycoproteins and antibody response elicited by formalin-inactivated vaccines in rabbits. Vaccine 7:8.

Hidayati DN, Untari T, Wibowo MH, Akiyama K, Asmara W (2018) Cloning and sequencing gB, gD, and gM genes to perform the genetic variability of bovine herpesvirus-1 from Indonesia. Vet World 11(9):12551261. https://doi.org/10.14202/vetworld.2018.1255-1261

Ho NI, Huis In 't Veld LGM, Raaijmakers TK, Adema GJ (2018) Adjuvants Enhancing Cross-Presentation by Dendritic Cells: The Key to More Effective Vaccines? Front Immunol 9:2874.

https://doi.org/10.3389/fimmu.2018.02874

Hong H, Akbari A, Wu J (2017) Small amphipathic peptides are responsible for the assembly of cruciferin nanoparticles. Sci Rep 7(1):7819. https://doi.org/10.1038/s41598-017-07908-z

J. CHARLES WHITBECK LJB, AND WILLIAM C. LAWRENCE (1988) Comparison of the Bovine Herpesvirus $.1 \mathrm{gl} \mathrm{Gene}$ and the Herpes Simplex Virus Type $1 \mathrm{gB}$ Gene. JOURNAL OF VIROLOGY 62(9):3319-3327.

Jefferson VA, Barber KA, El-Mayet FS, Jones C, Nanduri B, Meyer F (2018) Proteogenomic Identification of a Novel Protein-Encoding Gene in Bovine Herpesvirus 1 That Is Expressed during Productive Infection. Viruses 10(9). https://doi.org/10.3390/v10090499

Jiang L, Li X, Liu L, Zhang Q (2013) Cellular uptake mechanism and intracellular fate of hydrophobically modified pullulan nanoparticles. Int J Nanomedicine 8:1825-1834. https://doi.org/10.2147/IJN.S44342

Jones C, Chowdhury S (2007) A review of the biology of bovine herpesvirus type 1 (BHV-1), its role as a cofactor in the bovine respiratory disease complex and development of improved vaccines. Anim Health 
Res Rev 8(2):187-205. https://doi.org/10.1017/S146625230700134X

Kaur G, Chandra M (2016) Herpesvirus in Bovines: Importance of Bovine Herpesvirus Type 1. https://doi.org/10.5772/63157

Keil GM, Hohle C, Giesow K, Konig P (2005) Engineering glycoprotein B of bovine herpesvirus 1 to function as transporter for secreted proteins: a new protein expression approach. J Virol 79(2):791-799. https://doi.org/10.1128/JVI.79.2.791-799.2005

Keil GM, Klopfleisch C, Giesow K, Veits J (2010) Protein display by bovine herpesvirus type 1 glycoprotein B. Vet Microbiol 143(1):29-36. https://doi.org/10.1016/j.vetmic.2010.02.011

Kumar S, Anselmo AC, Banerjee A, Zakrewsky M, Mitragotri S (2015) Shape and size-dependent immune response to antigen-carrying nanoparticles. J Control Release 220(Pt A):141-148. https://doi.org/10.1016/j.jconrel.2015.09.069

LA. Babiuk SvDL-vdH, SK. Tikoo (1996) Immunology of bovine herpesvirus 1 infection. Veterinary Microbiology 53:12.

Lena Johrden MT, Ruth Lietz, Michae Storcksdieck genannt Bonsmann, Thomas Niezold1, Oliver Wildner WB, (2013) Comparison of polystyrene nanoparticles and UV-inactivated antigen-displaying adenovirus for vaccine delivery in mice. Virology Journal 10(108):5.

Levings RL, Collins JK, Patterson PA, Roth JA (2015) Virus, strain, and epitope specificities of neutralizing bovine monoclonal antibodies to bovine herpesvirus 1 glycoproteins gB, gC, and gD, with sequence and molecular model analysis. Vet Immunol Immunopathol 164(3-4):179-193.

https://doi.org/10.1016/j.vetimm.2015.02.009

Li L, Wang W, Tang J, Wang Y, Liu J, Huang L, Wang Y, Guo F, Wang J, Shen W, Belfiore LA (2019) Classification, Synthesis, and Application of Luminescent Silica Nanoparticles: a Review. Nanoscale Res Lett 14(1):190. https://doi.org/10.1186/s11671-019-3006-y

Liang B, Li N, Zhang S, Qi A, Feng J, Jing W, Shi C, Ma Z, Gao S (2019) Idarubicin-loaded methoxy poly(ethylene glycol)-b-poly(l-lactide-co-glycolide) nanoparticles for enhancing cellular uptake and promoting antileukemia activity. Int J Nanomedicine 14:543-556. https://doi.org/10.2147/IJN.S190027

M.J. Kaashoek FAMR, R.C. Ruuls, G.M. Keil'f, E. Thiry, Oirschot PPPaJTV (1998) Virulence, immunogenicity and reactivation of bovine herpesvirus 1 mutants with a deletion in the $\mathrm{gC}, \mathrm{gG}, \mathrm{gl}, \mathrm{gE}$, or in both the gl and gE gene. Vaccine 16:802-809.

Mahony D, Cavallaro AS, Mody KT, Xiong L, Mahony TJ, Qiao SZ, Mitter N (2014) In vivo delivery of bovine viral diahorrea virus, E2 protein using hollow mesoporous silica nanoparticles. Nanoscale 6(12):66176626. https://doi.org/10.1039/c4nr01202j 
Mody KT, Mahony D, Cavallaro AS, Zhang J, Zhang B, Mahony TJ, Yu C, Mitter N (2015) Silica Vesicle Nanovaccine Formulations Stimulate Long-Term Immune Responses to the Bovine Viral Diarrhoea Virus E2 Protein. PLoS One 10(12):e0143507. https://doi.org/10.1371/journal.pone.0143507

Mody KT, Mahony D, Zhang J, Cavallaro AS, Zhang B, Popat A, Mahony TJ, Yu C, Mitter N (2014) Silica vesicles as nanocarriers and adjuvants for generating both antibody and T-cell mediated immune resposes to Bovine Viral Diarrhoea Virus E2 protein. Biomaterials 35(37):9972-9983.

https://doi.org/10.1016/j.biomaterials.2014.08.044

Mody KT, Popat A, Mahony D, Cavallaro AS, Yu C, Mitter N (2013) Mesoporous silica nanoparticles as antigen carriers and adjuvants for vaccine delivery. Nanoscale 5(12):5167.

https://doi.org/10.1039/c3nr00357d

Mona Gupta AKG (2004) In vitro cytotoxicity studies of hydrogel pullulan nanoparticles prepared by aot/n-hexane micellar system. J Pharm Pharmaceut Sci (7((1):9.

Oleg Lunov, Tatiana Syrovets, G. Ulrich Nienhaus, Cornelia Loos, Johanna Beil, AnnaMusyanovych zV, Michael Delacher, Kyrylo Tron, ander zKL, z and Thomas Simmet (2011) Differential Uptake of Functionalized Polystyrene Nanoparticles by Human Macrophages and a Monocytic Cell Line. ACSNano 5:1657-1669. https://doi.org/10.1021/nn2000756

Park EJ, Bae E, Yi J, Kim Y, Choi K, Lee SH, Yoon J, Lee BC, Park K (2010) Repeated-dose toxicity and inflammatory responses in mice by oral administration of silver nanoparticles. Environ Toxicol Pharmacol 30(2):162-168. https://doi.org/10.1016/j.etap.2010.05.004

Pires de Mello CP, Bloom DC, Paixao IC (2016) Herpes simplex virus type-1: replication, latency, reactivation and its antiviral targets. Antivir Ther 21(4):277-286. https://doi.org/10.3851/IMP3018

Rietscher R, Schroder M, Janke J, Czaplewska J, Gottschaldt M, Scherliess R, Hanefeld A, Schubert US, Schneider M, Knolle PA, Lehr CM (2016) Antigen delivery via hydrophilic PEG-b-PAGE-b-PLGA nanoparticles boosts vaccination induced T cell immunity. Eur J Pharm Biopharm 102:20-31. https://doi.org/10.1016/j.ejpb.2016.02.014

S. VAN DRUNEN LITI-EL-VAN DEN HURK SG, 1- J. V. VAN DEN HURK, L A. BABIUK,AND P. TIJSSENÇ (1995) The Role of the Major Tegument Protein VP8 of Bovine Herpesvirus-1 in Infection and Immunity 1. VIROLOGy 1995(206):413-425.

Shaw AM, Braun L, Frew T, Hurley DJ, Rowland RR, Chase CC (2000) A role for bovine herpesvirus 1 (BHV1) glycoprotein $E(\mathrm{gE})$ tyrosine phosphorylation in replication of $B H V-1$ wild-type virus but not BHV-1 gE deletion mutant virus. Virology 268(1):159-166. https://doi.org/10.1006/viro.1999.0164

Slebioda TJ, Bojarska-Junak A, Cyman M, Landowski P, Kaminska B, Celinski K, Kmiec Z (2017) Expression of death receptor 3 on peripheral blood mononuclear cells differes in adult IBD patients and 
children with newly diagnosed IBD. Cytometry B Clin Cytom 92(2):165-169.

https://doi.org/10.1002/cyto.b.21372

Stano A, Nembrini C, Swartz MA, Hubbell JA, Simeoni E (2012) Nanoparticle size influences the magnitude and quality of mucosal immune responses after intranasal immunization. Vaccine 30(52):7541-7546. https://doi.org/10.1016/j.vaccine.2012.10.050

van Drunen Littel-van den Hurk S (2006) Rationale and perspectives on the success of vaccination against bovine herpesvirus-1. Veterinary Microbiology 113(3-4):275-282.

https://doi.org/10.1016/j.vetmic.2005.11.002

Xiaobo Fan1, FZ, XW, guoqiu wu (2016) Doxorubicin-triggered self-assembly of native amphiphilic peptides into spherical nanoparticles. Oncotarget 7(36).

XIAOPING LIANG CP, YUANHAO LI, LORNE A.BABIUK, and JACEK KOWAL (1995) Delineation of the Essential Function of Bovine Herpesvirus $1 \mathrm{gD}$ : An Indication for the Modulatory Role of gD in Virus Entry. virology 207:429-441.

Zhugunissov K, Bulatov Y, Taranov D, Yershebulov Z, Koshemetov Z, Zhunushov A, Renukaradhya GJ, Tabynov K, Abduraimov Y (2018) Beta-propiolactone inactivated bivalent bluetongue virus vaccine containing Montanide ISA-71VG adjuvant induces long-term immune response in sheep against serotypes 4 and 16 even after 3 years of controlled vaccine storage. Veterinary Microbiology 226:23-30. https://doi.org/10.1016/j.vetmic.2018.10.003

\section{Figures}


A
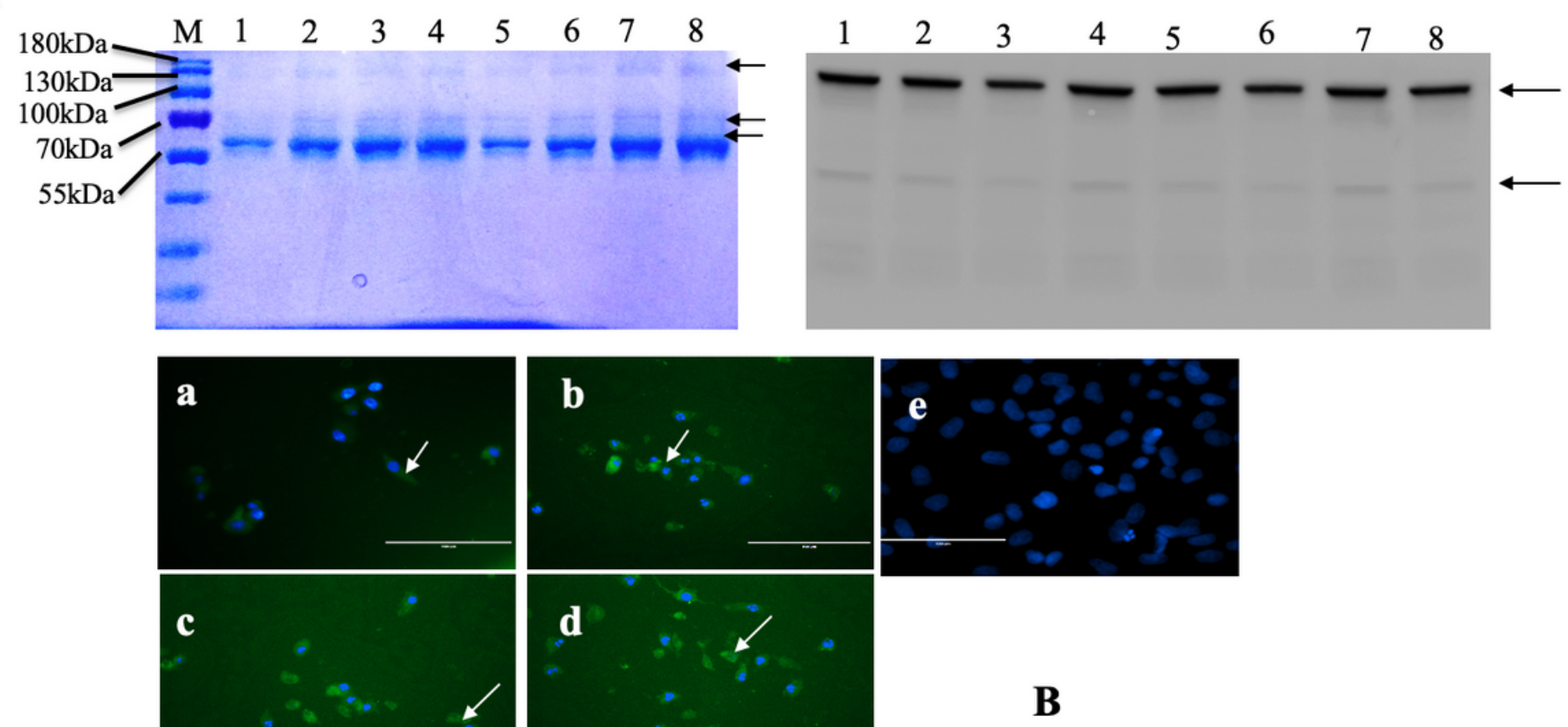

\section{Figure 1}

A: Assessment of gB, gC, gD, and gE proteins expressed by MDBK cells Lane M: marker; lanes 1 and 2: $\mathrm{gB}$; lanes 3 and 4: gC; lanes 5 and 6: gD; lanes 7 and 8: gE. Purity identification of gB gC gD gE proteins by SDS-PAGE and Western blotting (his tag). Lane: M: marker, 1\&2: gB, 3\&4: gC, 5\&6: gD, 7\&8: gE; his tag purified proteins contained 3 molecular weights, which was different with theory, further the bands were validated by Western Blotting (his tag), the tegument proteins was $130 \mathrm{kDa}$ 180kDa, just thin bands at $60 \mathrm{kDa}$. The molecular weights of the $\mathrm{gB}, \mathrm{gC}, \mathrm{gD}, \mathrm{gE}$ proteins differed from those expected based on the theoretical molecular weights of the native proteins (gB:101.19 kDa, gC 55.4 kDa, gD $44.9 \mathrm{kDa}, \mathrm{gE} 26.9$ $\mathrm{kDa}$; Uniprot.org). but there were two light-colored bands in the SDS-PAGE. B: MDBK cells were transfected with pcDNA4.0-gB/gC/gD/gE-his expression vectors and protein expression were assessed using an indirect immunofluorescence assay with rabbit anti-BoHV-1 polyclonal antibody. Antigenicity validation of $\mathrm{gB}, \mathrm{gC}, \mathrm{gD}, \mathrm{gE}$ proteins expressed in MDBK cell line by IFA with rabbit anti-BoHV-1 polyclonal antibody: a: gB; b:gC; c:gD; d:gE; e:Negative. a, b, c, d: MDBK cells were transfected with the pcDNA4.0-gBhis, pcDNA4.0-gC-his, pcDNA4.0-gD-his, and pcDNA4.0-gE-his plasmids, respectively, and expression of the $\mathrm{gB}, \mathrm{gC}, \mathrm{gD}$, and $\mathrm{gE}$ proteins (respectively) in the cytoplasm was assessed. e: MDBK cells were transfected with negative control pcDNA4.0-Myc-his plasmid. 

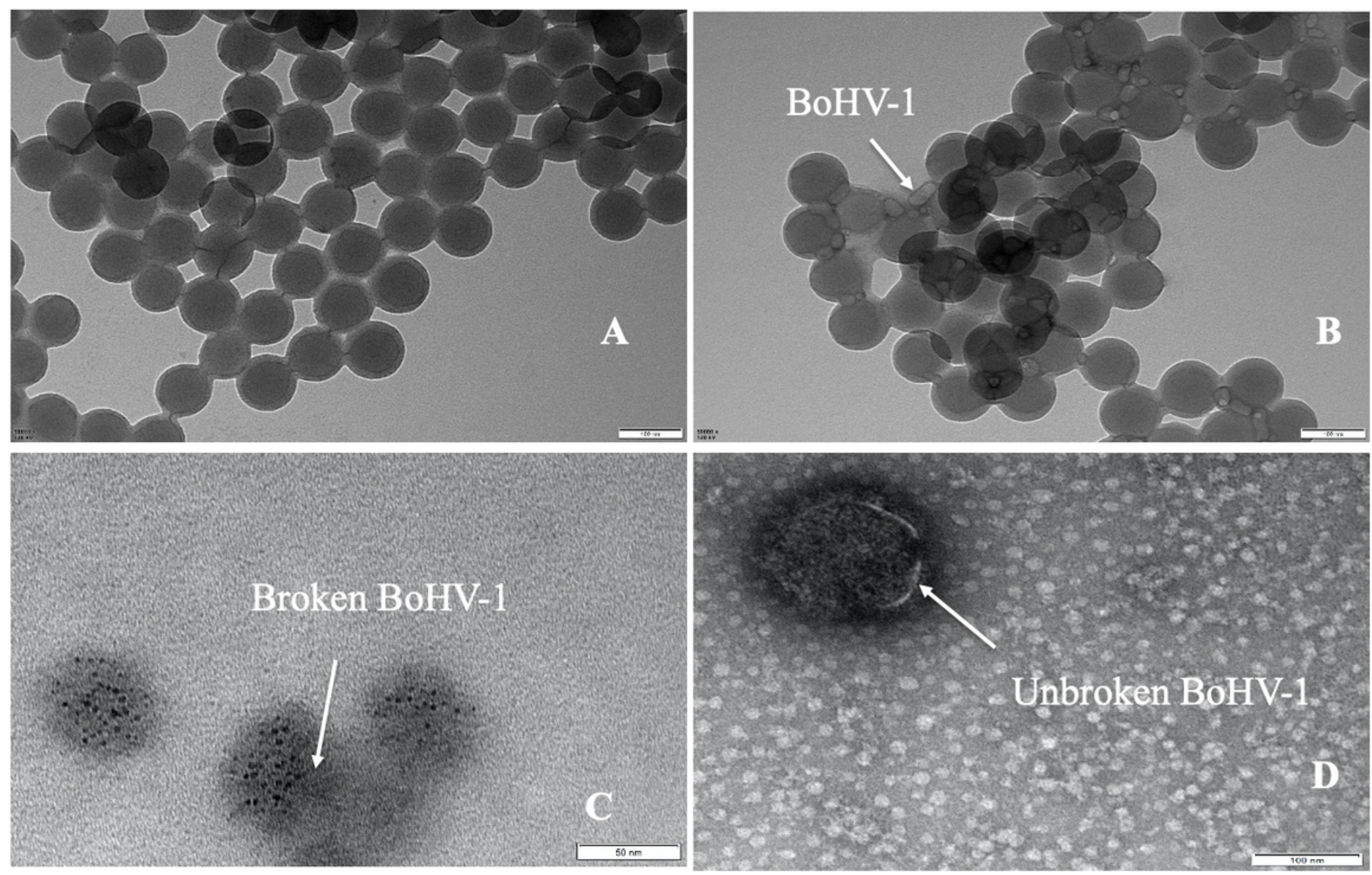

\section{Figure 2}

TEM of PS nanoparticles conjugated to BoHV-1 A: Naked PS nanoparticles scanned by TEM $(50,000 \times)$. The PS nanoparticles were monodisperse and spherical in shape. B: BoHV-1 was conjugated to PS nanoparticles scanned by TEM (50,000x). The broken BoHV-1 was conjugated to the surface of PS nanoparticles, but did not cover it fully. C: Broken BoHV-1『Centrifuged by $100,000 \times g \rrbracket$, no tegument layer was observed D: Unbroken BoHV-1 show a tegument layer
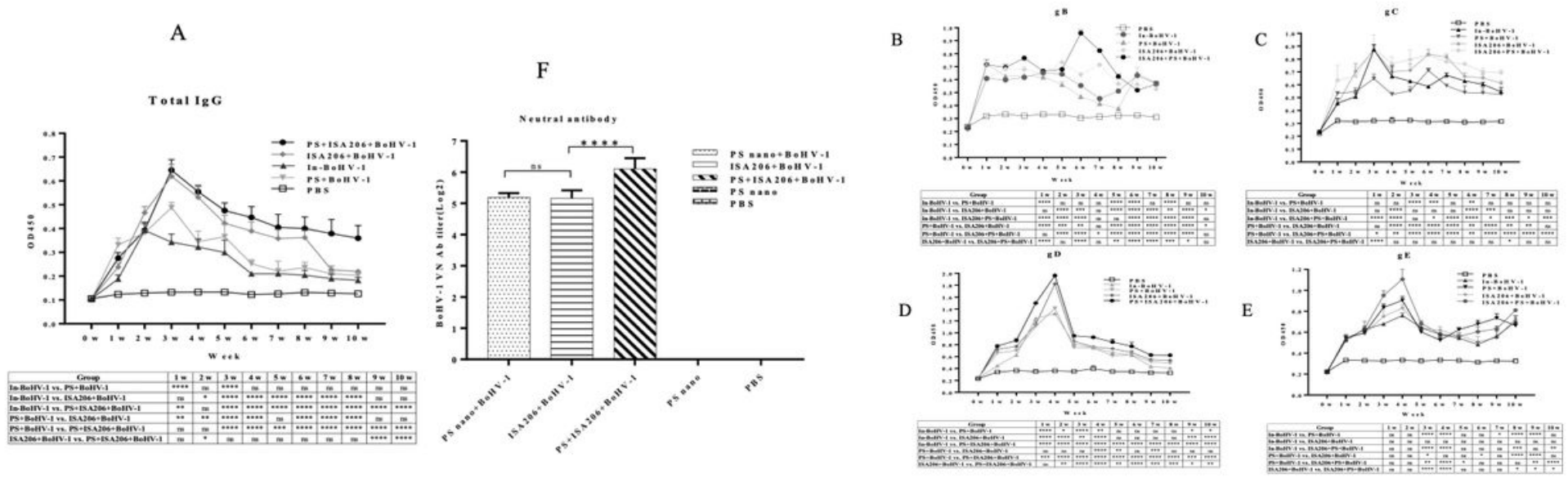

Figure 3 
Total IgG against BoHV-1/gB/gC/gD/gE was detected in serum. A: BoHV-1(100ng) was coated in wells and binding of total IgG in mouse serum was assessed by ELISA. B, C, D, E: gB, gC, gD, gE proteins (100 ng) were coated in wells and binding of total IgG in mouse serum was assessed by ELISA. F: Serum microneutralization assay 5 weeks post-immunization. Serum antibody neutralization of BoHV-1 $(25 \mu \mathrm{L}$ serum) was tested using a microneutralization assay 7 days post-immunization. Titers of neutralizing antibodies were calculated using the Karber method. Analysis of humoral immune responses showed that PS nanoparticles conjugated to BoHV-1 induced more durable antibody responses and higher neutralizing antibody titers than inactivated BoHV-1+ISA206. Asterisks indicate the magnitude of

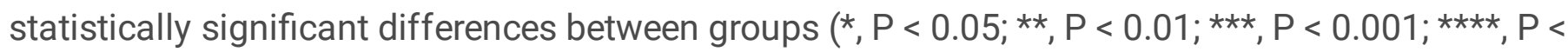
0.0001).

IL 4

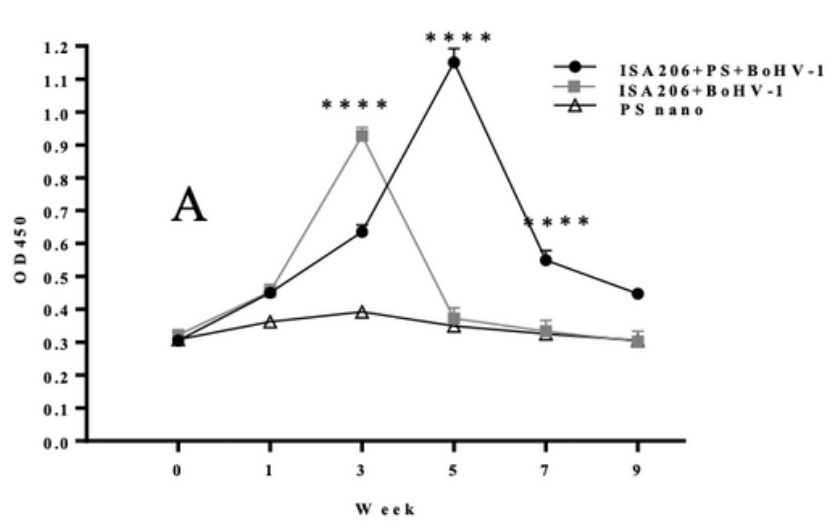

IFN- $\gamma$

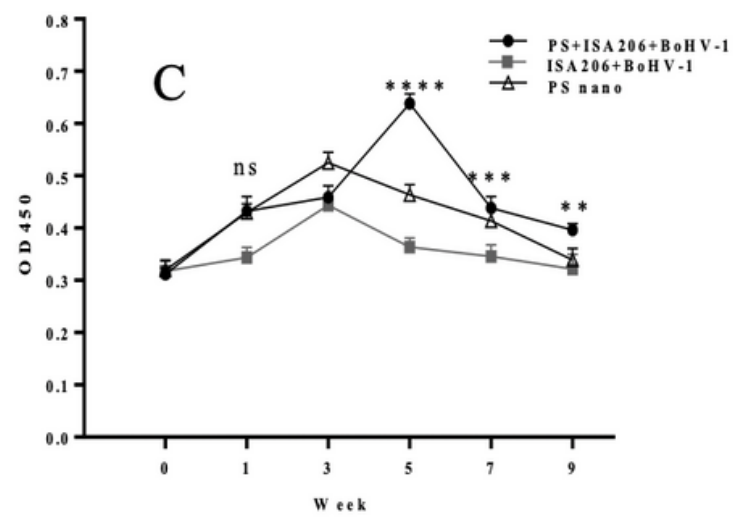

IL 6
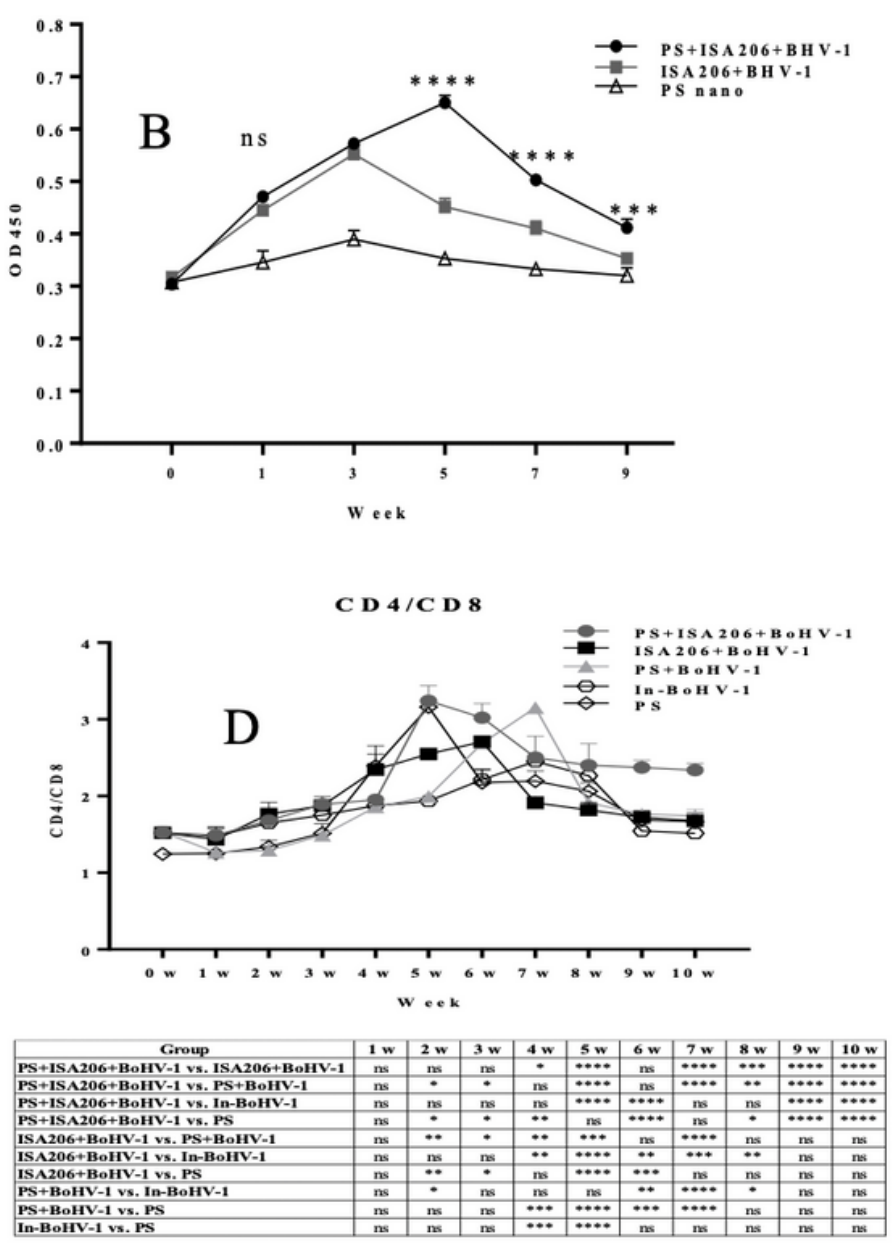

\section{Figure 4}

Levels of serum IL-4, IL-6, and IFN- $\gamma$ determined by ELISA and CD4/CD8 ratio determined by flow cytometry Levels of IL-4 (A), IL-6 (B) and IFN- $\gamma(C)$ were determined in serum $(25 \mu \mathrm{L})$ using ELISA kits. The results showed that using PS nanoparticles as a carrier improved cellular immune responses and induced higher IFN-y levels compared with ISA206. D: Frequencies of CD4+ and CD8+ T cells assessed by flow cytometry. Anticoagulant-treated blood $(200 \mu \mathrm{L})$ was lysed with red blood lysis buffer and lymphocytes were collected and stained with anti-CD4 (FITC) and anti-CD8 (PE) monoclonal antibodies. The stained 
lymphocytes were analyzed by flow cytometry. PS nanoparticles enhanced CD4+ T cell responses, irrespective of the presence or absence of ISA206 adjuvant. In the presence of ISA206, CD4+ T cell responses reached their maxima 1 week earlier than in the PS+BoHV-1 group and persisted longer. Asterisks indicate the magnitudes of statistically significant differences between groups $(*, P<0.05 ; * \star, P$ $<0.01 ; * \star \star, P<0.001 ; * \star \star \star, P<0.0001)$. 